\title{
Analisis Kinerja Aset Destinasi Wisata Waduk, Studi Kasus: Waduk Cijere, Kabupaten Bandung Barat
}

\author{
Analysis of Reservoir Tourism Asset Performance (Case Study: Cijere \\ Reservoir, West Bandung Regency)
}

\author{
Hennidah Karnawati ${ }^{1, \mathrm{a})}$, Putri Dewi Purnama ${ }^{1, \mathrm{~b})}$ \& Tiara Ulul Azmi ${ }^{1, \mathrm{c})}$ \\ ${ }^{1)}$ Manajemen Aset, Administrasi Niaga, Politeknik Negeri Bandung, Bandung \\ Koresponden : ${ }^{a}$ hennidah1962@yahoo.com \& b)putri.dewi@polban.ac.id, \\ c)tiaraulul@gmail.com
}

\begin{abstract}
ABSTRAK
Waduk Cijere merupakan salah satu luapan dari Waduk Saguling dengan luas 19,13 hektar yang berlokasi di Kecamatan Cipongkor, Kabupaten Bandung Barat. Waduk Cijere dipenuhi sampah, bebatuan, dan semak belukar yang mengakibatkan waduk tidak berfungsi dengan baik. Saat ini, Waduk Cijere hanya dimanfaatkan untuk kolam jaring apung. Tujuan penelitian ini adalah menganalisis lebih mendetail mengenai Kinerja Aset Destinasi Wisata Waduk Cijere, dilihat dari 4 kinerja yaitu kinerja fisik, fungsional, ulitias, dan keuangan. Metode penelitian yang digunakan adalah studi eksploratori (kualitatif dan kuantitatif). Teknik pengumpulan data menggunakan observasi, wawancara, studi dokumentasi, dan kuesioner. Hasil penelitian ini meliputi tidak adanya pemeliharaan pada Waduk Cijere mengakibatkan kondisi fisik buruk, Waduk Cijere tidak berfungsi sebagaimana mestinya, pemanfaatan Waduk Cijere belum optimal, terjadi penurunan pendapatan $10 \%$ hingga $40 \%$ dalam satu tahun, serta tidak adanya pendapatan yang masuk ke daerah karena belum adanya Izin Usaha Perikanan untuk Kolam Jaring Apung.
\end{abstract}

Kata Kunci : manajemen aset infrastruktur \& fasilitas, kinerja asset, kinerja fisik, kinerja fungsional, kinerja utilitas, kinerja keuangan, waduk.

\section{PENDAHULUAN}

Wisata Pariwisata merupakan aset yang potensial untuk dikembangkan sebagai sumber pendapatan daerah. Pendayagunaan potensi pariwisata daerah diharapkan dapat memberikan sumbangan bagi pembangunan ekonomi. Kemajuan perkembangan pariwisata suatu daerah bergantung pada jumlah wisatawan yang datang. Oleh karena itu, hal ini perlu didukung dengan peningkatan pemanfaatan daerah tujuan wisata, sehingga industri pariwisata akan berkembang dengan baik.

Waduk Cijere berlokasi di Jalan Warung Awi, Desa Sukamulya, Kecamatan Cipongkor, Kabupaten Bandung Barat. Waduk Cijere adalah waduk seluas 19,13 hektar yang merupakan luapan air Waduk Saguling dan mendapatkan aliran air dari anak sungai Cijere. Terdapat dua desa yang terkena genangan air Waduk Cijere yaitu Desa Sukamulya dan Desa Cicangkanghilir. 


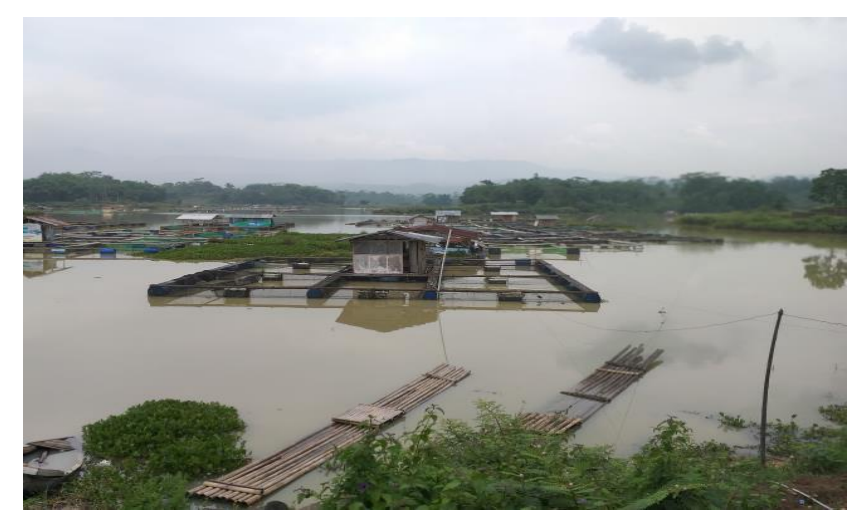

Gambar 1. Waduk Cijere
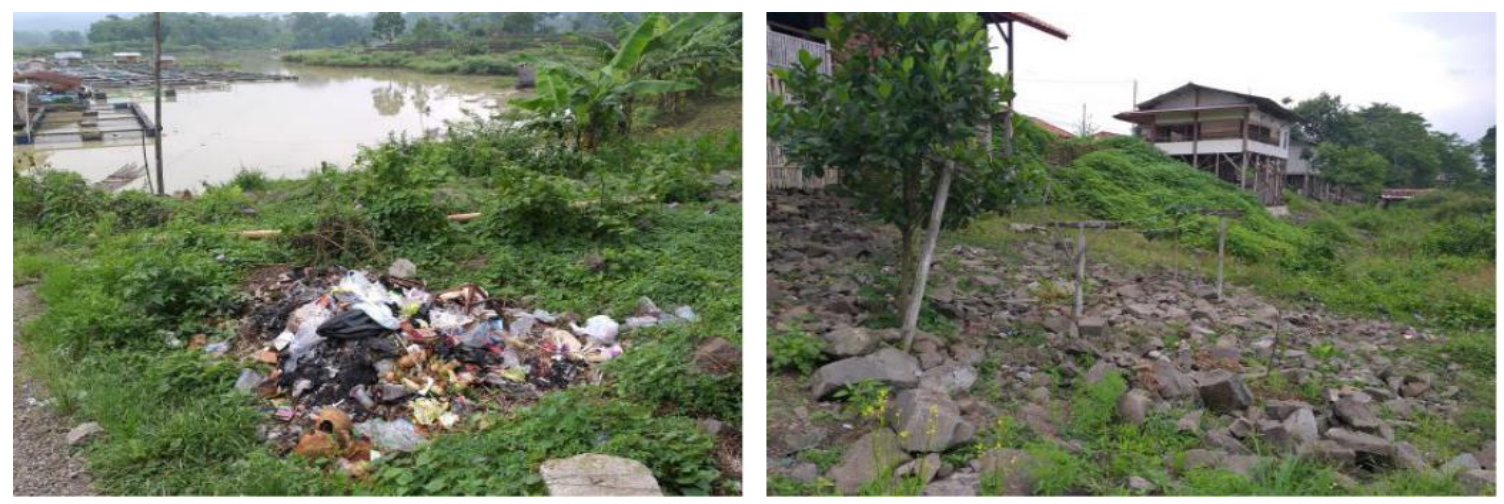

Gambar 2. Kondisi Sampah dan Bebatuan Sekitar Waduk Cijere
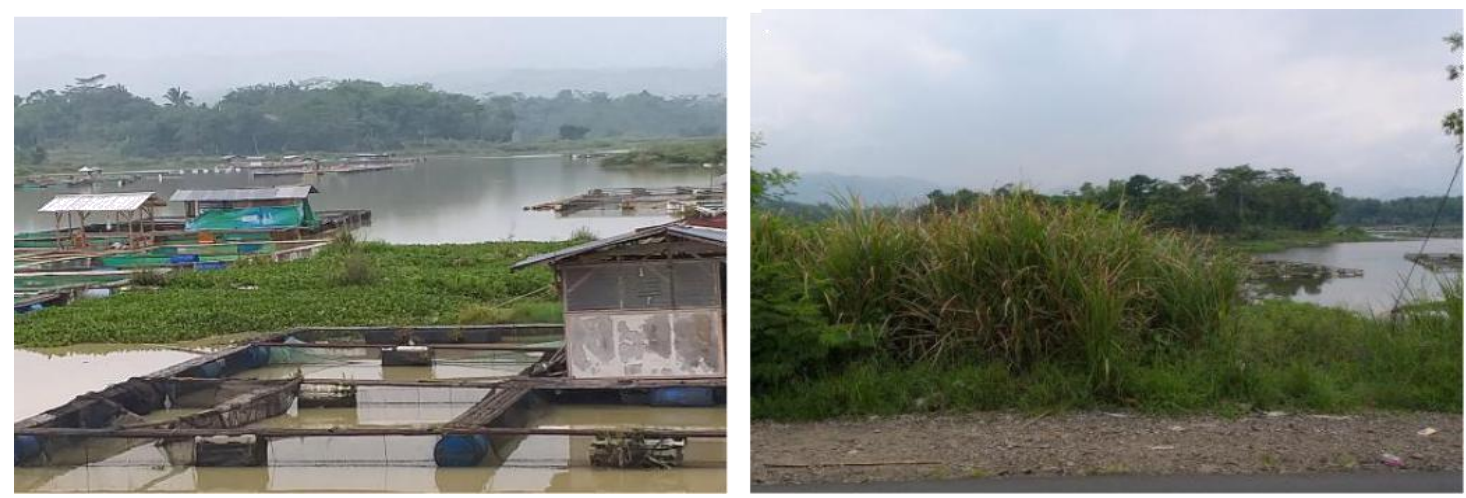

Gambar 3. Kondisi Semak Belukar dan Eceng Gondok di Waduk Cijere

Waduk Cijere dipenuhi sampah dan bebatuan seperti pada Gambar 2. Selain itu, banyak semak belukar dan tumbuhnya eceng gondok di Waduk Cijere seperti pada Gambar 3. Hal tersebut terjadi karena Waduk Cijere belum dikelola dengan baik. Kondisi tersebut mengakibatkan kotornya air waduk dan semakin dangkalnya Waduk. Waduk Cijere berfungsi sebagai penyeimbang aliran air ke Waduk Saguling saat Waduk Saguling kekurangan air. Namun, fungsi Waduk Cijere sebagai penyeimbang aliran air tidak berfungsi dengan baik. Akibatnya, air Waduk Cijere terlihat keruh karena aliran air yang didapatkan dari sungai Cijere tidak dapat dialirkan lagi ke Waduk Saguling. 

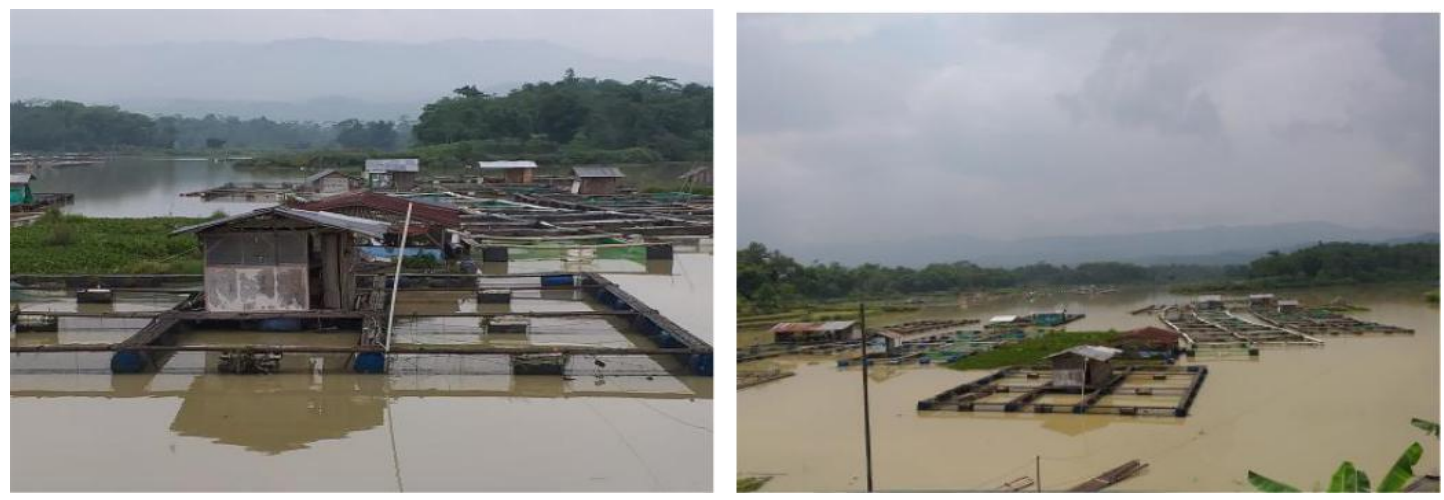

Gambar 4. Kolam jaring apung di Waduk Cijere

Selain digunakan untuk penyeimbang aliran air, saat ini Waduk Cijere dimanfaatkan untuk budidaya perikanan dengan menggunakan kolam jaring apung. Namun, pembuatan kolam jaring apung tersebut tidak ditata dengan baik karena secara bebas digunakan oleh berbagai pihak yang memiliki modal untuk membuat kolam jaring apung tersebut. Hal tersebut dapat dilihat pada Gambar 4. Akibatnya, Waduk Cijere tidak dapat berfungsi sebagaimana mestinya. Saat ini, terdapat 29 pemilik kolam jaring apung yang memanfaatkan Waduk Cijere tersebut.

Selain itu, tingkat penggunaan Waduk Cijere sangat minim karena hanya dimanfaatkan untuk kolam jaring apung sehingga belum adanya pendapatan yang masuk ke Pendapatan Asli Daerah (PAD). Hal tersebut terjadi karena pendapatan dari kolam jaring apung hanya didapatkan oleh pribadi. Berdasarkan fenomena yang terjadi pada Waduk Cijere, perlu dilakukan penelitian lebih detail mengenai Kinerja Aset Destinasi Wisata Waduk Cijere yang meliputi kinerja fisik, kinerja fungsional, kinerja utilitas, dan kinerja keuangan.

\section{STUDI PUSTAKA}

Aset merupakan suatu potensi yang bernilai dan dimiliki oleh individu maupun suatu instansi. Aset harus dijaga dan dikelola dengan baik agar nilai dari aset tersebut tidak mengalami penurunan baik dari segi fungsi maupun finansial. Namun, bukan suatu hal yang tidak mungkin apabila suatu aset dianggap tidak bernilai karena aset tersebut tidak dikelola dan dibiarkan terbengkalai begitu saja sehingga tidak berfungsi sebagaimana mestinya. Oleh karena itu, agar suatu aset dapat berfungsi maka perlu dilakukan evaluasi kinerja aset bersangkutan agar diketahui tindakan apa yang seharusnya dilakukan untuk mengelola suatu aset. Menurut Wirawan (2012), evaluasi merupakan riset untuk mengumpulkan, menganalisis, dan menyajikan informasi yang bermanfaat mengenai objek evaluasi, menilainya dengan membandingkannya dengan indikator evaluasi dan hasilnya dipergunakan untuk mengambil keputusan mengenai objek evaluasi.

Manajemen aset merupakan serangkaian kegiatan yang terkait dengan mengidentifikasi aset yang diperlukan, mengidentifikasi pendanaan, memperoleh aset, menyediakan sistem pendukung dan pemeliharaan untuk aset, menghapus atau mendaur ulang aset sehingga dapat memenuhi tujuan yang diinginkan secara efektif dan efisien (Hastings, 2010). Efektif berarti pengelolaan aset dapat mencapai hasil yang sesuai dengan tujuan. efisien berarti penggunaan sumber daya yang rendah dalam mendapatkan hasil yang tinggi (Sugiama, 2013). Sedangkan, Kaganova dan McKellar (dalam Hariyono, 2007) mendefinisikan manajemen aset merupakan proses pengambilan keputusan dan implementasi yang berkaitan dengan pengadaan, penggunaan, dan penghapusan properti. Siregar (2004) berpendapat bahwa terdapat 3 tujuan utama dari manajemen aset yaitu efisiensi pemanfaatan dan pemilikan, terjaga nilai ekonomis dan potensi yang dimiliki, dan objektivitas dalam pengawasan dan pengendalian peruntukkan, penggunaan, serta alih penguasaan. Salah satu aset yang perlu dikelola yaitu Waduk. Waduk 
merupakan salah satu aset infrastruktur dalam bidang pengairan. Menurut Notohadiprawiro et al (2006), waduk menurut pengertian umum merupakan tempat pada muka lahan untuk menampung air hujan secukupnya pada musim basah, sehingga air itu dapat dimanfaatkan pada musim kering atau langka air. Aset waduk perlu dimonitor dan dievaluasi kinerjanya agar berfungsi dengan baik terutama untuk fungsi pengairan. Menurut Suprayitno \& Soemitro (2018), Evaluasi Infrastruktur adalah tentang mengevaluasi infrastruktur yang terkait dengan operasi, pemeliharaan, kinerja fungsi, hasil evaluasi diperlukan untuk merumuskan program infrastruktur berikutnya pada pengembangan, operasi dan pemeliharaan.

Menurut Campbell (2011), siklus manajemen aset meliputi: 1) Strategi mencakup penilaian praktik pengelolaan aset, pengembangan strategi pengelolaan aset yang komprehensif, dan pengembangan program pengukuran dengan key performance indicators; 2) Rencana meliputi kegiatan mendefinisikan target, standar, kebijakan, dan prosedur yang jelas dan berfokus pada penyampaian strategi manajemen aset; 3) Evaluasi/Desain terdiri dari pengembangan program model yang menginformasikan keputusan pembelian dan mengevaluasi aset yang akan dibeli atau membuat desain untuk aset yang perlu dibuat; 4) Membuat/Pengadaan berupa melibatkan tindakan menciptakan, membangun, atau mengadakan aset yang telah direncanakan; 5) Operasi dapat dilakukan dengan menggunakan standar, kebijakan, dan prosedur dengan feedback ke TLAM; 6) Pemeliharaan meliputi kegiatan untuk mempertahankan aset untuk mendukung strategi dan target menggunakan standar, kebijakan, dan prosedur. Biaya pemeliharaan dan sumber daya dapat mengubah total biaya kepemilikan, dari biaya perbaikan hingga downtime; 7) Modifikasi tercermin dalam strategi, kebijakan, dan prosedur; 8) Penghapusan meliputi penghapusan, pemberhentian, atau likuidasi aset sesuai dengan strategi, kebijakan, dan prosedur.

Menurut Australian Asset Management Collaborative Group (2008), evaluasi merupakan suatu proses yang meliputi pengukuran, pelaporan, dan peninjauan kinerja aset yang dibandingkan dengan pengelolaan aset, tujuan organisasi dan pemerintah. Evaluasi kinerja aset merupakan kegiatan mengidentifikasi dan mencatat semua aset yang dibutuhkan untuk memberikan layanan dan menentukan seberapa efektif aset-aset tersebut mendukung layanan yang dipersyaratkan. Terdapat empat aspek yang diukur dalam kinerja aset menurut Australian Asset Management Collaborative Group (AAMCoG, 2008) yaitu kondisi fisik, fungsi, utilitas dan kinerja keuangan.

\section{Kondisi Fisik}

Suatu aset perlu dipertahankan dalam kondisi yang memadai untuk memenuhi sasaran dan tujuan yang relevan. Aspek fisik dapat dilakukan dengan cara :

a. Menetapkan kondisi aset sesuai dengan persyaratan pemberian layanan.

b. Memeriksa aset dan membandingkan kondisi yang sebenarnya dengan kondisi yang dibutuhkan.

c. Memprakirakan kondisi aset di masa depan.

2. Fungsional

Fungsionalitas aset adalah ukuran efektivitas aset dalam mendukung kegiatan yang akan dilakukan. Fungsi aset harus ditinjau secara berkala. Hal ini memungkinkan setiap dampak signifikan pada layanan yang akan diidentifikasi. Aspek fungsi digunakan untuk mengukur seberapa cocok aset dengan aktivitas dan fungsi yang didukungnya. Aspek fungsi dapat dilakukan dengan cara:

a. Menentukan peran yang dijalankan aset dalam mencapai hasil dari layanan yang diberikan.

b. Menentukan karakteristik fungsional dari aset yang dibutuhkan untuk mendukung kegiatan yang spesifik.

\section{Utilitas}

Aspek utilitas untuk mengukur seberapa intensif aset digunakan untuk memenuhi tujuan penyampaian layanan. Hal ini dapat dilakukan dengan cara : 
a. Mempertimbangkan seberapa sering aset digunakan dan apakah produktifitasnya dapat ditingkatkan.

b. Mengidentifikasi aset yang kurang dimanfaatkan dan tentukan alasan mengapa aset tersebut kurang dimanfaatkan (pertimbangkan kemungkinan kendala fisik, keusangan teknologi, dan kendala manajemen).

c. Meninjau pemanfaatan aset setiap tahun.

4. Kinerja Keuangan

Keuangan suatu aset harus dianalisis untuk menentukan apakah menyediakan layanan yang layak secara ekonomi. Hal ini dapat dilakukan dengan cara:

a. Memantau dan menilai biaya operasional dan proyeksi arus kas saat ini, termasuk belanja modal.

b. Menentukan tingkat pengembalian saat ini dan proyeksi di masa yang akan datang dari aset.

c. Menggunakan analisis Discounted Cash Flow untuk mengukur Net Present Value dan Internal Rate of Return dari aset.

\section{PENGUMPULAN DATA}

Tujuan dari penelitian ini adalah mendeskripsikan kinerja aset yang meliputi kinerja fisik, fungsional, utilitas, dan keuangan Waduk Cijere di Desa Sukamulya, Kecamatan Cipongkor, Kabupaten Bandung Barat, serta merumuskan alternatif solusi atas permasalahan yang terjadi pada Waduk Cijere tersebut. Penelitian ini menggunakan desain penelitian descriptive sequential mixed method design (MMR) yang mana desain ini menggabungkan pendekatan penelitian kuantitatif dengan penelitian kualitatif. Menurut Sugiama (2008), pendekatan kualitatif adalah prosedur suatu penelitian yang mengumpulkan data berupa kata-kata tertulis atau lisan dari orang-orang dan perilaku yang dapat diamati secara deskriptif. Sedangkan, penelitian kuantitatif yaitu penelitian yang data dan teknik analisis data berdasarkan pada angka-angka (Sugiama, 2013).

Metode penelitian yang digunakan dalam penelitian ini adalah deskriptif survey. Pengumpulan data dilakukan dengan rentang waktu (time horizon) yang bersifat cross section. Adapun teknik pengumpulan data primer dalam peneltian ini adalah sebagai berikut:

1. Observasi terhadap ketersediaan jenis-jenis aset yang dikelompokan ke dalam atraksi sarana dan prasarana, sistem informasi yang terdapat pada aset objek wisata waduk Cijere.

2. Kuesioner yang diisi oleh para pengunjung ke waduk Cijere dan masyarakat atau komunitas sekitar Waduk Cijere. Pertanyaan-pertanyaan yang terdapat dalam kuesioner cukup terperinci dan lengkap dan biasanya sudah menyediakan pilihan jawaban atau mmemberikan kesempatan responden menjawab secara bebas (Sekaran, 2011). Menurut Hair (2006) menyarankan bahwa jumlah sampel minimal adalah lima kali variabel yang dianalisis atau indikator pertanyaan. Jumlah variabel yang dianalisis dalam penelitian ini adalah satu. Oleh karena itu, sampel minimal dari penelitian ini adalah 5 orang.

Sedangkan teknik pengumpulan data sekunder dilakukan dengan studi dokumentasi untuk halhal yang berhubungan dengan keberadaan aset wisata waduk Cijere.

Unit analisis dari penelitian ini adalah aset berupa objek wisata waduk Cijere. Populasi dalam penelitian ini adalah semua wisatawan yang berkunjung ke Waduk Cijere dan komunitas di sekitar Waduk Cijere yang berjumlah sekitar 1.567 .684 orang. Unit observasi untuk penelitian kuantitatif adalah para pengunjung objek wisata waduk Cijere, sedangkan untuk penelitian kualitatif adalah para komunitas dan pemerintahan tingkat kecamatan dan desa dimana waduk Cijere berlokasi. Ukuran sampel untuk penelitian kuantitatif menggunakan rumus Francle yang menjelaskan bahwa ukuran sampel minimum untuk penelitian deskriptif adalah 100. Rumus untuk menghitung yakni $n=100 / 0,95 * 0,90=117$ orang. Sedangkan 
penelitian kualitatif adalah masing-masing 6 sd 12 perwakilan komunitas, kecamatan dan desa terkait.

Teknik sampling dalam penelitian kuantitatif adalah random sampling, dengan memilih secara random jumlah pengunjung ke waduk Cijere tiap hari dalam satu minggu. Data kuantitatif diolah menggunakan analisis deskriptif dengan bantuan SPSS 20. Ukuran deskriptif untuk data kuantitatif yang digunakan dasar analisis adalah mean dan $\mathrm{r}$ deviation standard untuk melihat bobot kepentingan dan rating dari setiap indikator penelitian. Sedangkan untuk penelitian kualitatif digunakan teknik purposive sampling. Pengolahan data kualitatif dilakukan secara manual menggunakan tabel silang, kemudian hasilnya dipakai untuk analisis content dan mengetahui tema. Hasil penelitian kuantitatif dan kualitatif menjadi dasar analisis untuk menjawab tujuan dari penelitian ini.

\section{ANALISIS PENELITIAN}

Penelitian ini dianalisis dengan menggunakan empat aspek meliputi aspek fisik,fungsional, utilitas, dan keuangan. Hasil dari penelitian ini adalah sebagai berikut :

1. Kondisi Fisik Aset

Evaluasi kondisi fisik aset Waduk Cijere yaitu meliputi kriteria kolam waduk, tanaman pengganggu, bangunan bantu, dan lingkungan sekitar waduk. Berikut ini adalah Tabel 1 yang menjabarkan lebih detail tentang evaluasi kondisi fisik Waduk Cijere.

Tabel 1. Evaluasi Kondisi Fisik Waduk Cijere

\begin{tabular}{|l|l|l|l|}
\hline $\begin{array}{l}\text { Kriteria } \\
\text { (Bria, 2017) }\end{array}$ & $\begin{array}{l}\text { Kondisi Normal } \\
\text { Waduk }\end{array}$ & Kondisi Existing & Keterangan \\
\hline $\begin{array}{l}\text { Kolam } \\
\text { Waduk } \\
\text { masih berada } \\
\text { pada dead } \\
\text { storage. }\end{array}$ & $\begin{array}{l}\text { Pada tahun 1982, } \\
\text { kedalaman Waduk } \\
\text { Cijere 30 meter. } \\
\text { Namun, pada tahun } \\
\text { 2018 kedalaman } \\
\text { Waduk Cijere 15 } \\
\text { meter. }\end{array}$ & $\begin{array}{l}\text { Dead storage atau kantong lumpur } \\
\text { merupakan ruangan khusus yang } \\
\text { disediakan untuk menampung sedimen } \\
\text { yang terbawa aliran sungai yang } \\
\text { bermuara di waduk. Pada Waduk Cijere } \\
\text { tidak terdapat kantong lumpur (dead } \\
\text { storage) yang sengaja disediakan oleh } \\
\text { pihak PT Indonesia Power. Namun, } \\
\text { endapan lumpur terjadi di Waduk Cijere. } \\
\text { Pada tahun 1982 kedalaman Waduk } \\
\text { Cijere adalah 30 meter, namun pada } \\
\text { tahun 2018 kedalaman Waduk Cijere } \\
\text { hanya 15 meter. Terjadi pendangkalan 15 } \\
\text { meter dalam kurun waktu 36 tahun. Hal } \\
\text { tersebut disebaban oleh adanya aktivitas } \\
\text { kolam jaring apung dan eceng gondok di } \\
\text { Waduk Cijere. }\end{array}$ \\
& $\begin{array}{l}\text { Tidak ada kotoran } \\
\text { atau ranting } \\
\text { pohon }\end{array}$ & Banyak sampah & $\begin{array}{l}\text { Pada Waduk Cijere terdapat banyak } \\
\text { sampah baik pada kolam waduk maupun } \\
\text { sekitar Waduk Cijere. Penyebab banyak } \\
\text { sampah di Waduk Cijere, yaitu: } \\
\text { 1. Aktivitas bangunan-bangunan liar di } \\
\text { sekitar Waduk Cijere. Hal ini terjadi } \\
\text { karena Jalan Warung Awi hanya } \\
\text { difungsikan sebagai }\end{array}$ \\
\hline & &
\end{tabular}


Tabel 1. Evaluasi Kondisi Fisik Waduk Cijere (Lanjutan)

\begin{tabular}{|c|c|c|c|}
\hline $\begin{array}{l}\text { Kriteria } \\
(\text { Bria, 2017) }\end{array}$ & $\begin{array}{l}\text { Kondisi Normal } \\
\text { Waduk }\end{array}$ & Kondisi Existing & Keterangan \\
\hline & & & $\begin{array}{l}\text { bendung, namun di pinggir jalan } \\
\text { tersebut dibangun beberapa bangunan } \\
\text { permanen tanpa mengurus aspek } \\
\text { legal. Bangunan ini seperti warung - } \\
\text { warung yang ada di pinggir jalan } \\
\text { Waduk Cijere. } \\
\text { 2. Kolam Jaring Apung yang sudah } \\
\text { tidak aktif. Kebanyakan kolam jaring } \\
\text { apung yang sudah tidak beroperasi, } \\
\text { bekas rangka kolam jaring apung } \\
\text { dibiarkan begitu saja di atas kolam } \\
\text { Waduk Cijere. } \\
\text { 3. Pembuangan sampah rumah tangga } \\
\text { oleh masyarakat yang dapat } \\
\text { menyebabkan Pendangkalan, } \\
\text { terganggunya habitat air waduk, } \\
\text { terhalangnya gorong-gorong } \\
\text { penyeimbang aliran air ke Waduk } \\
\text { Saguling sehingga menyebabkan } \\
\text { Waduk Cijere tidak dapat } \\
\text { melaksanakan lagi fungsinya sebagai } \\
\text { penyeimbang aliran. }\end{array}$ \\
\hline & & Air Keruh & $\begin{array}{l}\text { Kotoran yang ada di Waduk Cijere } \\
\text { terlihat juga dari air Waduk Cijere yang } \\
\text { keruh. Penyebab air Waduk Cijere keruh, } \\
\text { yaitu : } \\
\text { 1. Tidak mengalirnya air karena } \\
\text { gorong-gorong yang ada di bawah } \\
\text { jalan tersumbat karena sampah dan } \\
\text { bebatuan. } \\
\text { 2. Sisa pakan ikan yang tidak termakan } \\
\text { oleh ikan dan kotoran ikan dari } \\
\text { aktivitas kolam jaring apung. } \\
\text { 3. Rapuhnya rangka kolam jaring apung } \\
\text { yang terbuat dari bambu atau bekas } \\
\text { peralatan kolam jaring apung. }\end{array}$ \\
\hline & & $\begin{array}{l}\text { Banyaknya } \\
\text { bebatuan }\end{array}$ & $\begin{array}{l}\text { Pada awalnya tidak ada permasalahan } \\
\text { pada bebatuan tersebut karena tujuan } \\
\text { awal adanya bebatuan tersebut } \\
\text { digunakan untuk menopang } \\
\text { pembangunan jalan agar tidak roboh. } \\
\text { Namun, bebatuan yang telah ditata } \\
\text { dengan baik, disalahgunakan oleh }\end{array}$ \\
\hline
\end{tabular}


Tabel 1. Evaluasi Kondisi Fisik Waduk Cijere (Lanjutan)

\begin{tabular}{|c|c|c|c|}
\hline $\begin{array}{l}\text { Kriteria } \\
\text { (Bria, 2017) }\end{array}$ & $\begin{array}{l}\text { Kondisi Normal } \\
\text { Waduk }\end{array}$ & Kondisi Existing & Keterangan \\
\hline \multirow[t]{3}{*}{$\begin{array}{l}\text { Kolam } \\
\text { Waduk }\end{array}$} & $\begin{array}{l}\text { Endapan lumpur } \\
\text { masih berada } \\
\text { pada dead } \\
\text { storage. }\end{array}$ & $\begin{array}{l}\text { Pada tahun } 1982, \\
\text { kedalaman Waduk } \\
\text { Cijere } 30 \text { meter. } \\
\text { Namun, pada tahun } \\
2018 \text { kedalaman } \\
\text { Waduk Cijere } 15 \\
\text { meter. }\end{array}$ & $\begin{array}{l}\text { Dead storage atau kantong lumpur } \\
\text { merupakan ruangan khusus yang } \\
\text { disediakan untuk menampung sedimen } \\
\text { yang terbawa aliran sungai yang } \\
\text { bermuara di waduk. Pada Waduk Cijere } \\
\text { tidak terdapat kantong lumpur (dead } \\
\text { storage) yang sengaja disediakan oleh } \\
\text { pihak PT Indonesia Power. Namun, } \\
\text { endapan lumpur terjadi di Waduk Cijere. } \\
\text { Pada tahun } 1982 \text { kedalaman Waduk } \\
\text { Cijere adalah } 30 \text { meter, namun pada } \\
\text { tahun } 2018 \text { kedalaman Waduk Cijere } \\
\text { hanya } 15 \text { meter. Terjadi pendangkalan } 15 \\
\text { meter dalam kurun waktu } 36 \text { tahun. Hal } \\
\text { tersebut disebabkan oleh adanya aktivitas } \\
\text { kolam jaring apung dan eceng gondok di } \\
\text { Waduk Cijere. }\end{array}$ \\
\hline & $\begin{array}{l}\text { Tidak ada kotoran } \\
\text { atau ranting } \\
\text { pohon }\end{array}$ & Banyak sampah & $\begin{array}{l}\text { Pada Waduk Cijere terdapat banyak } \\
\text { sampah baik pada kolam waduk maupun } \\
\text { sekitar Waduk Cijere. Penyebab banyak } \\
\text { sampah di Waduk Cijere, yaitu: } \\
\text { 4. Aktivitas bangunan-bangunan liar di } \\
\text { sekitar Waduk Cijere. Hal ini terjadi } \\
\text { karena Jalan Warung Awi hanya } \\
\text { difungsikan sebagai }\end{array}$ \\
\hline & & & $\begin{array}{l}\text { bendung, namun di pinggir jalan } \\
\text { tersebut dibangun beberapa bangunan } \\
\text { permanen tanpa mengurus aspek } \\
\text { legal. Bangunan ini seperti warung - } \\
\text { warung yang ada di pinggir jalan } \\
\text { Waduk Cijere. } \\
\text { 5. Kolam Jaring Apung yang sudah } \\
\text { tidak aktif. Kebanyakan kolam jaring } \\
\text { apung yang sudah tidak beroperasi, } \\
\text { bekas rangka kolam jaring apung } \\
\text { dibiarkan begitu saja di atas kolam } \\
\text { Waduk Cijere. } \\
\text { 6. Pembuangan sampah rumah tangga } \\
\text { oleh masyarakat yang dapat } \\
\text { menyebabkan Pendangkalan, } \\
\text { terganggunya habitat air waduk, } \\
\text { terhalangnya gorong-gorong } \\
\text { penyeimbang aliran air ke Waduk } \\
\text { Saguling sehingga menyebabkan } \\
\text { Waduk Cijere tidak dapat } \\
\text { melaksanakan lagi fungsinya sebagai } \\
\text { penyeimbang aliran. }\end{array}$ \\
\hline
\end{tabular}


Tabel 1. Evaluasi Kondisi Fisik Waduk Cijere (Lanjutan)

\begin{tabular}{|c|c|c|c|}
\hline $\begin{array}{l}\text { Kriteria } \\
\text { (Bria, 2017) }\end{array}$ & $\begin{array}{l}\text { Kondisi Normal } \\
\text { Waduk }\end{array}$ & Kondisi Existing & Keterangan \\
\hline & & Air Keruh & $\begin{array}{l}\text { Kotoran yang ada di Waduk Cijere } \\
\text { terlihat juga dari air Waduk Cijere yang } \\
\text { keruh. Penyebab air Waduk Cijere keruh } \\
\text { yaitu: } \\
\text { 4. } \\
\text { Tidak mengalirnya air karena } \\
\text { gorong-gorong yang ada di bawah } \\
\text { jalan tersumbat karena sampah dan } \\
\text { bebatuan. } \\
\text { 5. Sisa pakan ikan yang tidak termakan } \\
\text { oleh ikan dan kotoran ikan dari } \\
\text { aktivitas kolam jaring apung. } \\
\text { 6. Rapuhnya rangka kolam jaring apung } \\
\text { yang terbuat dari bambu atau bekas } \\
\text { peralatan kolam jaring apung. }\end{array}$ \\
\hline & & $\begin{array}{l}\text { Banyaknya } \\
\text { bebatuan }\end{array}$ & $\begin{array}{l}\text { Pada awalnya tidak ada permasalahan } \\
\text { pada bebatuan tersebut karena tujuan } \\
\text { awal adanya bebatuan tersebut } \\
\text { digunakan untuk menopang } \\
\text { pembangunan jalan agar tidak roboh. } \\
\text { Namun, bebatuan yang telah ditata } \\
\text { dengan baik, disalahgunakan oleh }\end{array}$ \\
\hline & & & $\begin{array}{l}\text { masyarakat dan digunakan sebagai } \\
\text { material untuk membangun } \\
\text { bangunan-bangunan yang ada di } \\
\text { pinggir jalan. Oleh karena itu, sisa } \\
\text { bebatuan tersebut menjadi tersebar } \\
\text { dan mengganggu kolam Waduk } \\
\text { Cijere. Bebatuan ini juga } \\
\text { mengakibatkan pendangkalan Waduk } \\
\text { Cijere karena bebatuan ini akan } \\
\text { terbawa oleh air Waduk Cijere ketika } \\
\text { pasang. }\end{array}$ \\
\hline & $\begin{array}{l}\text { Pagar di } \\
\text { sekeliling kolam } \\
\text { baik }\end{array}$ & $\begin{array}{l}\text { Tidak terdapat } \\
\text { pagar di } \\
\text { sekeliling Waduk } \\
\text { Cijere. }\end{array}$ & $\begin{array}{l}\text { Hal ini terjadi karena pada saat } \\
\text { terbentuk Waduk Cijere, tidak ada } \\
\text { pengelolaan oleh PT Indonesia Power } \\
\text { sehingga tidak ada pagar yang } \\
\text { dibangun sebagai keamanan waduk. }\end{array}$ \\
\hline $\begin{array}{l}\text { Bangunan } \\
\text { Bantu }\end{array}$ & $\begin{array}{l}\text { Tersedia dan } \\
\text { berfungsi. } \\
\text { Bangunan } \\
\text { bendung terdiri }\end{array}$ & $\begin{array}{l}\text { Tersedia, namun } \\
\text { tidak berfungsi. }\end{array}$ & $\begin{array}{l}\text { Pada Waduk Cijere terdapat } \\
\text { bangunan bantu berupa bendung. } \\
\text { Terdapat } 2 \text { bendung di Waduk Cijere. } \\
\text { Namun, hanya terdapat Bangunan }\end{array}$ \\
\hline
\end{tabular}


Tabel 1. Evaluasi Kondisi Fisik Waduk Cijere (Lanjutan)

\begin{tabular}{|c|c|c|c|}
\hline $\begin{array}{l}\text { Kriteria } \\
\text { (Bria, 2017) }\end{array}$ & $\begin{array}{l}\text { Kondisi Normal } \\
\text { Waduk }\end{array}$ & Kondisi Existing & Keterangan \\
\hline & $\begin{array}{l}\text { dari bangunan } \\
\text { tubuh bendung, } \\
\text { bangunan intake, } \\
\text { pembilas, dan } \\
\text { bangunan } \\
\text { perlengkapan. }\end{array}$ & & $\begin{array}{l}\text { tubuh bendung di Waduk Cijere. Untuk } \\
\text { bangunan intake, bangunan pembilas, } \\
\text { dan bangunan perlengkapan tidak ada. } \\
\text { Saat ini, kondisi bangunan tubuh } \\
\text { bendung rusak berat. Pada bagian kanan } \\
\text { bangunan bendung sudah bocor. Selain } \\
\text { itu, bangunan bendung amper terendam } \\
\text { oleh lumpur, tanaman liar, dan bebatuan } \\
\text { yang ada di Waduk Cijere. Hal ini terjadi } \\
\text { karena tidak adanya pemeliharaan pada } \\
\text { bending di Waduk Cijere. }\end{array}$ \\
\hline $\begin{array}{l}\text { Bangunan } \\
\text { Bantu }\end{array}$ & $\begin{array}{l}\text { Tersedia dan } \\
\text { berfungsi. } \\
\text { Bangunan } \\
\text { bendung terdiri } \\
\text { dari bangunan } \\
\text { tubuh bendung, } \\
\text { bangunan intake, } \\
\text { pembilas, dan } \\
\text { bangunan } \\
\text { perlengkapan. }\end{array}$ & $\begin{array}{l}\text { Tersedia, namun } \\
\text { tidak berfungsi. }\end{array}$ & $\begin{array}{l}\text { Pada Waduk Cijere terdapat bangunan } \\
\text { bantu berupa bendung. Terdapat } 2 \\
\text { bendung di Waduk Cijere. Namun, hanya } \\
\text { terdapat Bangunan tubuh bendung di } \\
\text { Waduk Cijere. Untuk bangunan intake, } \\
\text { bangunan pembilas, dan bangunan } \\
\text { perlengkapan tidak ada. Saat ini, kondisi } \\
\text { bangunan tubuh bendung rusak berat. } \\
\text { Pada bagian kanan bangunan bendung } \\
\text { sudah bocor. Selain itu, bangunan } \\
\text { bendung amper terendam oleh lumpur, } \\
\text { tanaman liar, dan bebatuan yang ada di } \\
\text { Waduk Cijere. Hal ini terjadi karena } \\
\text { tidak adanya pemeliharaan pada bending } \\
\text { di Waduk Cijere. }\end{array}$ \\
\hline $\begin{array}{l}\text { Lingkungan } \\
\text { Sekitar } \\
\text { Waduk }\end{array}$ & $\begin{array}{l}\text { Tersedia } \\
\text { aksesibilitas } \\
\text { menuju waduk }\end{array}$ & Tersedia & $\begin{array}{l}\text { Tersedia aksesibilitas berupa jalan untuk } \\
\text { menuju ke Waduk Cijere. Jalan tersebut } \\
\text { memiliki konstruksi aspal dengan lebar } \\
\text { jalan } 3 \text { meter. Jalan tersebut masuk ke } \\
\text { dalam klasifikasi jalan khusus karena } \\
\text { jalan tersebut dibangun dan dipelihara } \\
\text { oleh instansi yaitu oleh PT Indonesia } \\
\text { Power. Namun, jalan tersebut merupakan } \\
\text { CSR dari PT Indonesia Power untuk } \\
\text { masyarakat desa. }\end{array}$ \\
\hline
\end{tabular}


Tabel 1. Evaluasi Kondisi Fisik Waduk Cijere (Lanjutan)

\begin{tabular}{|l|l|l|l|}
\hline $\begin{array}{l}\text { Kriteria } \\
(\text { Bria, 2017) }\end{array}$ & $\begin{array}{l}\text { Kondisi Normal } \\
\text { Waduk }\end{array}$ & Kondisi Existing & Keterangan \\
\hline & & & $\begin{array}{l}\text { hal irigasi. Hal tersebut terjadi karena } \\
\text { posisi lahan pertanian lebih tinggi dari } \\
\text { posisi Waduk Cijere sehingga perlu } \\
\text { menggunakan alat bantu agar lahan } \\
\text { pertanian tersebut didukung oleh Waduk } \\
\text { Cijere. }\end{array}$ \\
\hline & $\begin{array}{l}\text { Tersedia } \\
\text { penggunaan lahan } \\
\text { yang didukung } \\
\text { oleh waduk }\end{array}$ & Tersedia & $\begin{array}{l}\text { Di lingkungan sekitar Waduk Cijere } \\
\text { terdapat lahan pertanian berupa sawah di } \\
\text { sekitar waduk. Namun, lahan pertanian } \\
\text { tersebut belum didukung oleh Waduk } \\
\text { Cijere dalam }\end{array}$ \\
\hline
\end{tabular}

Berdasarkan hasil evaluasi, kondisi fisik Waduk Cijere buruk seperti yang disajikan pada Tabel 1 terjadi penurunan kondisi fisik waduk yaitu pendangkalan 15 meter, terdapat kotoran dan tanaman pengganggu pada kolam waduk, tidak adanya fasilitas keamanan waduk, dan kerusakan pada bangunan tubuh bendung di Waduk Cijere. Hal ini juga didukung oleh hasil kuesioner yaitu $61,1 \%$ dari responden mengatakan bahwa Waduk Cijere tidak bersih dan 80,6\% mengatakan bahwa terdapat tanaman pengganggu di Waduk Cijere. Berdasarkan wawancara dengan pihak desa bahwa penyebab utama kondisi eksisting Waduk Cijere yang buruk terjadi karena tidak adanya pengelolaan maupun pemeliharaan dari pihak PT Indonesia Power selaku pemilik waduk.

2. Kinerja Fungsional Aset

Evaluasi fungsi aset dengan membandingkan peran aset dengan fungsi seharusnya. Hasil evaluasi fungsi waduk disajikan dalam Tabel 2.

Tabel 2. Evaluasi Kinerja Fungsi Waduk Cijere

\begin{tabular}{|l|l|l|}
\hline 0 & Kondisi Existing & Keterangan \\
\hline $\begin{array}{l}\text { Penyedia Air } \\
\text { Langsung }\end{array}$ & Tidak ada & $\begin{array}{l}\text { Waduk Cijere tidak berfungsi sebagai penyedia air } \\
\text { langsung karena kondisi air Waduk Cijere keruh, sehingga } \\
\text { tidak bisa secara langsung dijadikan sebagai air minum. }\end{array}$ \\
\hline $\begin{array}{l}\text { Hidroelektrisita } \\
\text { s (PLTA) }\end{array}$ & Tidak ada & Tidak tersedia. \\
\hline $\begin{array}{l}\text { Kontrol } \\
\text { Sumber Daya }\end{array}$ & Tidak ada & $\begin{array}{l}\text { Salah satu fungsi kontrol sumber daya air yaitu irigasi. } \\
\text { Fungsi Waduk Cijere sebagai irigasi persawahan tidak } \\
\text { dapat dilaksanakan karena posisi Waduk Cijere yang ada di } \\
\text { bagian hilir dan posisi persawahan lebih tinggi daripada } \\
\text { waduk, sehingga air waduk tidak dapat dialirkan secara } \\
\text { alami ke sawah. Irigasi persawahan dapat dilakukan apabila } \\
\text { air Waduk Cijere dialirkan ke sawah dengan menggunakan } \\
\text { pompa. }\end{array}$ \\
\hline
\end{tabular}


Tabel 2. Evaluasi Kinerja Fungsi Waduk Cijere (Lanjutan)

\begin{tabular}{|l|l|l|}
\hline $\begin{array}{l}\text { Fungsi Dipersyaratkan } \\
\text { (Bria, 2017) }\end{array}$ & $\begin{array}{l}\text { Kondisi } \\
\text { Existing }\end{array}$ & Keterangan \\
\hline Penyeimbang Aliran & $\begin{array}{l}\text { Ada, namun } \\
\text { tidak berfungsi } \\
\text { lagi. }\end{array}$ & $\begin{array}{l}\text { Waduk bisa digunakan untuk menyeimbangkan aliran air } \\
\text { dengan menampung air saat aliran air deras dan } \\
\text { melepaskannya kembali saat aliran melambat. Untuk } \\
\text { bisa menjalankan fungsi ini tanpa campur tangan pompa, } \\
\text { waduk membutuhkan pengendalian melalui pintu air di } \\
\text { bendungan. Fungsi Waduk Cijere sebagai penyeimbang } \\
\text { aliran tidak berfungsi dengan baik. Hal tersebut terjadi } \\
\text { karena tidak adanya pintu air, hanya terdapat bangunan } \\
\text { tubuh bendung dan bangunan tubuh bendung yang ada di }\end{array}$ \\
$\begin{array}{ll}\text { Waduk Cijere dalam kondisi rusak berat sehingga } \\
\text { Waduk Cijere tidak dapat menyeimbangkan aliran air ke } \\
\text { Waduk Saguling. Berdasarkan hasil wawancara dengan } \\
\text { Sekretaris Desa Cicangkanghilir, hal ini terjadi karena } \\
\text { tidak adanya pengelolaan dan pemeliharaan terhadap } \\
\text { Waduk Cijere }\end{array}$ \\
\hline Rekreasi & $\begin{array}{l}\text { Ada, namun } \\
\text { belum optimal. }\end{array}$ & $\begin{array}{l}\text { Fungsi rekreasi di Waduk Cijere secara tidak langsung } \\
\text { sudah ada, namun belum optimal. Hal tersebut dilihat } \\
\text { dari banyaknya masyarakat yang berkunjung ke Waduk } \\
\text { Cijere dengan alasan untuk makan di saung di sekitar } \\
\text { Waduk Cijere, menikmati pemandangan alam, dan } \\
\text { keindahan Waduk Cijere. Berdasarkan hasil kuesioner, } \\
81,08 \% \text { dari responden berkunjung ke Waduk Cijere } \\
\text { karena alasan pemandangan alam yang indah, berlibur, } \\
\text { dan makan di saung sekitar waduk. Namun, belum } \\
\text { adanya fasilitas yang mendukung kegiatan rekreasi } \\
\text { tersebut. }\end{array}$ \\
\hline
\end{tabular}

Berdasarkan Tabel 2 dapat diketahui bahwa kinerja fungsi dari Waduk Cijere telah melaksanakan dua fungsi yaitu sebagai penyeimbang aliran dan rekreasi namun tidak berfungsi dengan baik. Terdapat 68,2\% dari responden yang mengatakan bahwa Waduk Cijere tidak berfungsi dengan baik. Berdasarkan hasil evaluasi, kinerja fungsi Waduk Cijere tidak berfungsi sebagaimana mestinya.

3. Kinerja Utilitas Aset

Menurut Peraturan Menteri PUPR Nomor 27 Tahun 2015, waduk dapat dimanfaatkan untuk budi daya perikanan maupun kegiatan olahraga. Hasil evaluasi kinerja utilitas Waduk Cijere disajikan dalam Tabel 3.

Tabel 3. Evaluasi Kinerja Utilitas Waduk Cijere

\begin{tabular}{|l|l|l|}
\hline $\begin{array}{l}\text { Pemanfaatan Waduk } \\
\text { (PERMEN PUPR } \\
\text { Nomor 27 Tahun 2015) }\end{array}$ & Kondisi Existing & Keterangan \\
\hline Kegiatan olahraga & Tidak ada & $\begin{array}{l}\text { Saat ini, Waduk Cijere tidak dimanfaatkan } \\
\text { untuk kegiatan olahraga. }\end{array}$ \\
\hline
\end{tabular}


Tabel 3. Evaluasi Kinerja Utilitas Waduk Cijere (Lanjutan)

\begin{tabular}{|l|l|l|}
\hline $\begin{array}{l}\text { Pemanfaatan Waduk } \\
\text { (PERMEN PUPR Nomor 27 } \\
\text { Tahun 2015) }\end{array}$ & Kondisi Existing & Keterangan \\
\hline Budi daya perikanan & $\begin{array}{l}\text { Ada, yaitu Kolam Jaring Apung } \\
\text { (KJA). }\end{array}$ & $\begin{array}{l}\text { Pemanfaatan Waduk Cijere } \\
\text { sebagai budidaya perikanan } \\
\text { sudah ada Petani ikan } \\
\text { menggunakan Waduk Cijere } \\
\text { sebagai mata pencahariannya } \\
\text { dalam mengoperasikan kolam } \\
\text { jaring apung. Namun, status } \\
\text { kolam jaring apung ini belum } \\
\text { diakui secara legal. Terdapat 46 } \\
\text { unit KJA di Waduk Cijere. }\end{array}$ \\
\hline
\end{tabular}

Kolam jaring apung merupakan sebuah sistem dengan memanfaatkan jaring yang diapungkan di air sebagai pemeliharaan ikan. Kolam jaring apung ini merupakan salah satu mata pencaharian masyarakat sekitar Waduk Cijere. Kolam jaring apung ini merupakan salah satu kegiatan budidaya perikanan yang meningkatkan perekonomian masyarakat sekitar Waduk Cijere. Adapun jumlah Kolam Jaring Apung di Waduk Cijere disajikan dalam Tabel 4. 
Tabel 4. Jumlah Kolam Jaring Apung di Waduk Cijere

\begin{tabular}{|l|l|l|l|}
\hline No & Nama Pemilik KJA & Jumlah Unit KJA & Jumlah Kotak KJA \\
\hline 1 & Dedi & 1 unit & 4 kotak \\
\hline 2 & Tata & 2 unit & 8 kotak \\
\hline 3 & Ruswandi & 1 unit & 4 kotak \\
\hline 4 & Asep & 1 unit & 4 kotak \\
\hline 5 & Hambali & 3 unit & 12 kotak \\
\hline 6 & Anjar & 2 unit & 8 kotak \\
\hline 7 & Yaya & 2 unit & 8 kotak \\
\hline 8 & Pudin & 2 unit & 8 kotak \\
\hline 9 & Bachtiar & 3 unit & 12 kotak \\
\hline 10 & Ajid & 1 unit & 4 kotak \\
\hline 11 & Udin & 1 unit & 4 kotak \\
\hline 12 & Bunbun & 1 unit & 4 kotak \\
\hline 13 & Endin & $11 / 2$ unit & 6 kotak \\
\hline 14 & Usman & 1 unit & 4 kotak \\
\hline 15 & Adung & 2 unit & 8 kotak \\
\hline 16 & Dadan & 2 unit & 8 kotak \\
\hline 17 & Rohman & 2 unit & 8 kotak \\
\hline 18 & Haris & 3 unit & 12 kotak \\
\hline 19 & Ahud & 1 unit & 4 kotak \\
\hline 20 & Jajang & $1 / 2$ unit & 2 kotak \\
\hline 21 & Encep Supriatna & 2 unit & 8 kotak \\
\hline 22 & Ujun & 1 unit & 4 kotak \\
\hline 23 & Endang & 1 unit & 4 kotak \\
\hline 24 & Udin & 1 unit & 4 kotak \\
\hline 25 & Dahiman & 1 unit & 4 kotak \\
\hline 26 & Oha & $1 / 2$ unit & 2 kotak \\
\hline 27 & Kosim & 4 unit & 16 kotak \\
\hline 28 & Engkus & 2 unit & 8 kotak \\
\hline 29 & Ade Sohidin & $1 / 2$ unit & 2 kotak \\
\hline & Jumlah & 46 Unit & 184 Kotak \\
\hline & Berasarkn & \\
\hline
\end{tabular}

Berdasarkan pemanfaatan Waduk Cijere, tingkat utilitas Waduk Cijere saat ini masih rendah. Hal tersebut dilihat dari pemanfaatan Waduk Cijere hanya dimanfaatkan untuk kolam jaring apung. Selain itu, 86,1\% dari responden mengatakan bahwa penggunaan Waduk Cijere belum optimal. Oleh karena itu, perlu pengembangan Waduk Cijere agar pemanfaatan waduk menjadi optimal.

Tingkat utilitas Waduk Cijere yang belum optimal, membuat masyarakat Desa Sukamulya maupun Cicangkanghilir ingin memanfaatkan Waduk Cijere agar menghasilkan pendapatan daerahnya. Terdapat $100 \%$ dari responden mengatakan bahwa Waduk Cijere berpotensi untuk dikembangkan. Hal tersebut didukung dengan kondisi penggunaan lahan sekitar Waduk Cijere adalah pertanian berupa sawah. Luas lahan dan penggunaannya di Desa Sukamulya dan Desa Cicangkanghilir yang disajikan dalam Tabel 5. 
Tabel 5. Luas Penggunaan Lahan Desa Sukamulya dan Desa Cicangkanghilir

\begin{tabular}{|l|l|l|}
\hline Penggunaan & Luas Wilayah & Luas Wilayah \\
\cline { 2 - 3 } & Desa Sukamulya & Desa Cicangkanghilir \\
\hline Pemukiman & 52 ha & 15,82 ha \\
\hline Persawahan & 203 ha & 76,67 ha \\
\hline Perkebunan & 54 ha & - \\
\hline Penggunaan & Luas Wilayah & Luas Wilayah \\
\cline { 2 - 3 } & Desa Sukamulya & Desa Cicangkanghilir \\
\hline Pekarangan & 15 ha & 85,79 ha \\
\hline Perkantoran & 4 ha & 1,65 ha \\
\hline Prasarana Umum Lainnya & 44 ha & 0,4831 ha \\
\hline Total Luas & 372 ha & 180,4831 ha \\
\hline
\end{tabular}

\section{Kinerja Keuangan}

Pencapaian keuangan yang dihasilkan dari suatu aset, dapat dijadikan sebagai acuan apakah aset tersebut telah dikelola dengan baik atau tidak. Begitupun dengan Waduk Cijere, apabila biaya yang dikeluarkan lebih kecil dibanding dengan pendapatan yang dihasilkan maka kinerja keuangan Waduk Cijere dapat dikatakan baik. Oleh karena itu, dilakukan evaluasi terhadap kinerja keuangan Waduk Cijere yang terdiri dari biaya operasi dan pemeliharaan KJA, pendapatan, dan hasil produksi KJA.

1. Biaya

Indikator biaya meliputi biaya langsung dan tidak langsung.

a. Biaya langsung adalah biaya investasi yang dikeluarkan saat suatu aset dibeli atau dibangun. Untuk biaya pembuatan Waduk Cijere tidak ada karena sudah +36 tahun semenjak dibangunnya bendungan Saguling pada tahun 1982. Sehingga untuk mendapatkan biaya langsung terkait Waduk Cijere sudah tidak ada, karena investasi terjadi sejak 36 tahun yang lalu. Adapun biaya investasi untuk pembuatan kolam jaring apung yaitu Rp 20.000.000 untuk setiap unit kolam yang terdiri dari 4 kotak dengan ukuran $7 \times 7$ meter.

b. Biaya tidak langsung adalah biaya yang dikeluarkan untuk operasi dan pemeliharaan aset. Waduk Cijere tidak dikelola sama sekali oleh PT Indonesia Power sehingga tidak ada biaya untuk pengoperasian waduk dan pemeliharaan waduk oleh PT Indonesia Power sehingga akan mencantumkan biaya operasi dan pemeliharaan Kolam Jaring Apung (KJA) yang beroperasi di kolam Waduk Cijere. Biaya operasi KJA Lihat pada Tabel 6.

Tabel. 6 Biaya Operasi KJA Tahun 2018

\begin{tabular}{|l|l|l|}
\hline Keterangan & Jumlah Biaya Satu Masa Panen & $\begin{array}{l}\text { Total Biaya Operasi Tahun } \\
2018\end{array}$ \\
\hline Biaya 100 kg benih & $\mathrm{Rp} 3.500 .000$ & $\mathrm{Rp} 10.500 .000$ \\
\hline Biaya 1000 kg pakan & $\mathrm{Rp} 9.000 .000$ & $\mathrm{Rp} \mathrm{27.000.000}$ \\
\hline Total & $\operatorname{Rp~} 12.500 .000$ & $\mathrm{Rp} \mathrm{37.500.000}$ \\
\hline
\end{tabular}

Sedangkan, biaya pemeliharaan KJA yaitu biaya yang dikeluarkan untuk penggantian bambu setiap 1 tahun sekali. Biaya penggantian bambu KJA yaitu Rp 210.000, dimana harga 1 bambu adalah Rp 35.000 dan membutuhkan 6 bambu untuk setiap unit KJA. 
2. Pendapatan

Pendapatan yang dihasilkan dari Waduk Cijere adalah pendapatan dari pengoperasian kolam jaring apung. Kolam jaring apung menghasilkan produksi ikan nila, ikan mas, ikan patin, dan ikan gurame. Produksi ikan dilakukan 3 kali dalam 1 tahun. Oleh karena itu, pendapatan yang dihasilkan didapat 3 kali dalam 1 tahun. Pada awalnya, setiap aktivitas yang menggunakan Waduk Cijere dikenakan bagi hasil. Dimana pendapatan yang dihasilkan 40\% untuk pihak PT Indonesia Power, 20\% untuk pihak desa, 10\% untuk pihak pengelola, dan untuk penggarap $30 \%$. Pendapatan yang didapat dari produksi ikan disajikan dalam Tabel 7.

Tabel 7. Pendapatan dari Waduk Cijere

\begin{tabular}{|l|l|l|l|l|}
\hline Tahun 2018 & $\begin{array}{l}\text { Jumlah Hasil } \\
\text { Produksi }\end{array}$ & Harga/kg & Pendapatan & $\begin{array}{l}\text { Penurunan } \\
\text { Pendapatan }\end{array}$ \\
\hline Masa Panen Ke 1 & $950 \mathrm{~kg}$ & $\mathrm{Rp} 20.000$ & $\mathrm{Rp} 19.000 .000$ & - \\
\hline Masa Panen Ke 2 & $850 \mathrm{~kg}$ & $\mathrm{Rp} \mathrm{20.000}$ & $\mathrm{Rp} 17.000 .000$ & $10,53 \%$ \\
\hline Masa Panen Ke 3 & $600 \mathrm{~kg}$ & $\mathrm{Rp} 20.000$ & $\mathrm{Rp} 12.000 .000$ & $29,41 \%$ \\
\hline \multicolumn{2}{|l|}{ Total Pendapatan } & $\mathrm{Rp} \mathrm{48.000.000}$ & \\
\hline
\end{tabular}

Berdasarkan Tabel 7, pendapatan yang dihasilkan dari produksi ikan yang dibudidayakan di Waduk Cijere semakin menurun. Berdasarkan hasil wawancara dengan pengelola KJA Waduk Cijere, penurunan pendapatan mencapai $10 \%$ hingga 40\%. Hal tersebut terjadi karena kuantitas ikan yang diproduksi semakin menurun karena banyak ikan yang mati akibat penyakit kulit dan insang. Salah satu penyebabnya adalah kualitas air yang jelek sehingga menurunkan hasil produksi ikan. Apabila terdapat penurunan pendapatan dari produksi ikan, maka pendapatan yang didapat oleh PT Indonesia Power pun mengalami penurunan.

Pada saat ini pendapatan yang dihasilkan dari Waduk Cijere tersebut hanya didapat oleh pemilik kolam jaring apung, tidak ada retribusi yang masuk ke kas desa maupun PT Indonesia Power. Hal ini terjadi karena kolam jaring apung Waduk Cijere belum memiliki izin usaha perikanan seperti yang tercantum dalam Peraturan Daerah Provinsi Jawa Barat Nomor 14 Tahun 2002 Tentang Usaha Perikanan dan Retribusi Usaha Perikanan dan Peraturan Daerah Nomor 2 Tahun 2010 Tentang Pengelolaan Perikanan.

\section{KESIMPULAN}

Berdasarkan hasil penelitian dapat disimpulkan bahwa kinerja aset Waduk Cijere kurang baik. Kinerja fisik Waduk Cijere buruk karena tidak adanya pemeliharaan pada Waduk Cijere. Hal ini mengakibatkan Waduk Cijere tidak berfungsi sebagaimana mestinya karena tidak adanya upaya untuk mempertahankan fungsi Waduk Cijere. Pemanfaatan Waduk Cijere juga belum optimal. Saat ini Waduk Cijere hanya dimanfaatkan untuk kolam jaring apung. Selain itu, kinerja keuangan yang dihasilkan dari Pemanfaatan Waduk Cijere juga menurun yaitu terjadi penurunan pendapatan $10 \%$ hingga $40 \%$ dalam satu tahun, dan tidak adanya pendapatan yang masuk ke daerah karena belum adanya Izin Usaha Perikanan (IUP) untuk Kolam Jaring Apung (KJA) Waduk Cijere.

Dari simpulan diatas, dapat diketahui permasalahan kondisi fisik berdampak pada kinerja fungsional, utilitas, dan keuangan Waduk Cijere. Oleh karena itu, terdapat dua rekomendasi solusi pemecahan masalah yang terjadi pada aset Waduk Cijere yaitu dengan revitalisasi Waduk Cijere, dan optimasi penggunaan dan pemanfaatan Waduk Cijere. 


\section{DAFTAR PUSTAKA}

Bria, M., Sutirto, \& Anastasia H. Muda. (2017). Penilaian Kinerja Embung Haliwen Berdasarkan Kriteria Pemeliharaan Embung Irigasi. Politeknologi: Kupang.

Campbell, J. a. F. (2011). Asset Management Excellence Optimizing Equipment Life-Cycle Decisoins. CRC Press.

Hair, J. F. (2006). Multivariate Data Analysis. Edisi ke 5. Gramedia Pustaka Utama: Jakarta.

Hariyono, A. (2007). Prinsip \& Teknik Manajemen Kekayaan Negara. Departemen Keuangan Negara Republik Indonesia. Jakarta.

Hastings, N.A.J. (2010). Physical Asset Management. Springer. London.

PerMen PUPR 27/15. Peraturan Menteri Pekerjaan Umum dan Perumahan Rakyat Republik Indonesia Nomor 27/PRT/M/2015 tentang Bendungan. Kementerian Pekerjaan Umum dan Perumahan Rakyat Republik Indonesia: Jakarta.

Notohadiprawiro, T., S. Sukadarmodjo, \& M. Dradjad. (2006). Beberapa Fakta dan Angka Tentang Lingkungan Fisik Waduk Wonogiri dan Kepentingannya sebagai Dasar Pengolahan. Ilmu Tanah: Repro.

Sekaran, U. (2011). Metode Penelitian untuk Bisnis. Salemba Empat. Jakarta.

Siregar, D. (2004). Manajemen Aset. Gramedia Pustaka Utama. Jakarta.

Sugiama, A. G. (2008). Metode Riset Bisnis dan Manajemen. Guardaya Intimarta. Bandung. Sugiama, A. G. B. (2013). Manajemen Aset Pariwisata. Guardaya Intimatra. Bandung.

Suprayitno, H. \& Soemitro, R.A.A. (2018). Pemikiran Awal tentang Prinsip Dasar Manajemen Aset Infrastruktur. Jurnal Manajemen Aset Infrastruktur \& Fasilitas, Vol. 2, No. 1, Maret 2018.

Wirawan. (2012). Evaluasi; Teori, Model, Standar, Aplikasi dan Profesi. PT Rajagrafindo Persada. Jakarta. 


\section{(e)ISSN 2615-1847 (p)ISSN 2615-1839}

Jurnal Manajemen Aset Infrastruktur \& Fasilitas - Vol. 4, No. 4, Oktober 2020 